from universal space, and thus the temperature in its interior is gradually increased to an immeasurable extent. Then the moment arrives when the exterior crust can no longer resist the rising pressure of the inclosed masses, which have, of course, become gaseous. An explosion must result. The greater part of the mass which is converted into gas is dispersed over a great space, and thus by far the greater part of the accumulated heat is converted into gravitation and force of rotation o the dispersed masses. Now the second portion of the solar period begins, which, as a process of condensation of cosmical nebulæe and subsequent slow cooling of the bodies formed by this condensation, has been frequently discussed since the days of Laplace."

This is I Ierr Loschmidt's idea of the typical course of a cosmical period, if fully developed according to the laws of heat. But he thinks that it is highly probable that this full development can be but rarely realised in the case of a solar system, since the duration of the heat-absorption will generally find a premature end in the impossibility of the external crust resisting the enormous pressure of the inclosed gases until the maximum of temperature is arrived at. "Upon our sun, for instance, in a state of equilibrium of temperature, the surface temperature would be $-140^{\circ}$ C., while at a depth of half a (German) mile we already would find a temperature of $3,000^{\circ} \mathrm{C}$. Here all known substances would be in a state of liquid incandescence. The solid crust could therefore not be thicker than half a (German) mile. In this case, therefore, the typical course described would evidently be interrupted prematurely by an explosion.

"The consequences of a solar eruption of this kind are naturally very different under different conditions. Thus with a comparatively small accumulation of heat and corresponding low tension, the result would be simply the return to incandescence of a dark heavenly body, while with greater concentration of heat some portions 'may be separated from the principal mass and carried to great distances, where, forming themselves into planets, they would revolve round the principal mass in elliptical orbits. This theory, therefore, easily explains the origin of planets, like those of our system, and the manner in which they were carried to their respective places and are provided with sheir forces of rotation and revolution, and also how after all in the principal solar mass a quantity of heat would remain, which would cause a far higher temperature upon its surface than exists at present upon our sun. The principal solar mass would thus be again enabled to radiate light and heat to its planets and into the universe, until again the moment of solidification and rebeginning of absorption of heat has arrived. The total resuit under the most varying circumstances always remains the same : periodicity of the dynamical solar phenomena.

"If finally we look for proofs for our theory in the heavens, we direct our attention to dark burnt-out suns on the one hand and to suddenly appearing new suns on the other. It is strange that modern times have given examples of both classes of phenomena. As a representative of the first class we have the dark companion of Sirius, calculated in advance by Bessel from the disturbances, and actually seen by A. Clark and Pond in 1862 . This enormous mass has only just been rendered visible by the most powerful instruments, although it is nearly seven times the size of our sun. A second example is the companion of Procyon which, though calculated with certainty, has not yet been seen on account of its still greater darkness. Examples of the other class we have in the well-known new stars of Tycho Brahe and Kepler, besides the new star in Corona of I866 and the one recently seen by Schmidt and others in Cygnus (December, 1876). In hoth these latter cases eruptions of incandescent hydrogen were proved beyond doubt by spectral observations."

\section{THE METEOR}

A METEOR of unusual brilliance was seen of the "fire-ball" type on Friday night by several correspondents. All agree that the time was about 9.50 , the moon at the time being in her second quarter, and about $30^{\circ}$ above the horizon in the west-southwest. At Twickenham its observed course was from south-west to north-west passing the azimuth of the moon at the time $69^{\circ}$ from south to west, at an altitude of about $14^{\circ}$, its path being nearly jarallel to the horizon, or declining very slightly towards its disappearance, which was sudden, at $9 \mathrm{~h}$. 52m. 305. Greenwich mean time. Colour, bright emerald green; apparent diameter, about one-third of that of the moon, this being the greater diameter of the elliptical figure. The light thrown by the meteor in this locality was decidedly green. Mr. Lecky, writing from the Scientific Club, states that the course of the meteor was about $90^{\circ}$ below the moon, its motion very: slow, and it became extinouished rather suddenly, without any apparent bursting, when it had passed about the same distance to the north of the moon. The meteor appeared to Mr. Lecky to be about the same size as the moon. Mr. L. J. Whalley saw it from the Brompton Road. Facing west he saw it pass from south to north, its path being inclined downwards at a few degrees to the horizon, and its altitude abont $30^{\circ}$. The fore-part appeared rounded in shape, and of a bright green colour (like nickel sulphate), whilst the tail tapered off, and was of a red to a purplish tint.

Mr. Walter Fowler saw it from Cambridge. Its path, he states, was from south to north, almost parallel with the horizon, with a slight declination northwards. Iuring its course, which lasted about twenty seconds, it emitted innumerable sparks variegated in colour.

Another correspondent saw it from London Street, Greenwich. Its apparent altitude, he states, was about $28^{\circ}$ or $30^{\circ}$ above the western horizon, and it passed horizontally over the tops of the houses in a direction about two points to the west of north. He observed it for about three seconds. It appeared in passing under the moon to be about $6^{\circ}$ or $8^{\circ}$ underneath her lower limb, and about the same degree of brightness and equal to it in size. The meteor, he states, had a tail about equal to six or seven diameters of its nucleus; the central part of the tail and the nucleus were of a pale orange hue and fringed with violet rays. The tail was in the line of motion, and was not a perfect cone, but appeared to expand into a fin-like form at the extremity.

Mr. F. J. Richardson, of Dimchurch, near Rugby, observed the meteor, "of considerable size," cross the sky, apparently about $30^{\circ}$ above the horizon. The direction of its path was from south to west, and its colour appeared a mixture of orange and green. It remained visible for about thirty or forty seconds, and then suddenly disappeared.

Mr. R. Langdon, writing from Silverton Station, Devon, states that it moved slowly towards Ursa Major, and exploded a little beyond that constellation. Its colours were, first, very pale blue (nearly white), then deep blue, and finally, the several fragments after explosion were blood-red. Dr. Morison saw it from Jersey. When first seen it was about $30^{\circ}$ from the zenith in a direction nearly due north. The diameter of its disc, which was apparently circular, was rather more than half that of the full moon, which it far surpassed in brilliancy, shining with a beautiful white light. The meteor descended towards the horizon, leaving a very faint luminous trail behind it, and was lost to sight, while still remaining entire, behind a high wall. It was altogether visible about thirty seconds.

Our Paris correspondent writes that a splendid meteor was seen in the department of Aisne and at Versailles about ten o'clock in the evening, travelling westwards at a small altiturle. It was in diameter about one-sixth that of the moon, the brilliancy admirable, and the tail four or five times the length of the moon's diameter. No noise was heard.

Mr. Denning, of Bristol, writing to the Times, states that the meteor had a very long path, almost horizontal, from east to west, which it traversed with a gradual motion, casting off a short train of sparks as it sailed along, and showing sensible variations in the brilliancy of its pear-shaped nucleus. The position of the observed part of its path was noted from $1^{\circ}$ above the star Spica Virginis to $6^{\circ}$ above the moon, but to inclucle the whole extent of its visible course the line must be extended in each direction, and have a length of at least $75^{\circ}$ from, say, slightly below Alpha Libræ to slightly above Alpha Leonis, running almost parallel with the ecliptic. The meteor was considerably brighter than Venus, and perhaps equal to a body onefourth of the moon's diameter. Mr. H. Middleton Rogers states that while walking along a footpath close to Knole Park, he saw it passing apparently from south to north, very nearly parallel to the horizon, with a very slight declination towards the north. When he first saw it it was about $5^{\circ}$ from the moon, (taking the moon's diameter roughly at half a degree.) It passed slowly along about $3^{\circ}$ below the moon, or about $30^{\circ}$ above the horizon, and continued its course for about $20^{\circ}$ further towards the north, when it suddenly disappeared. The light was of a very pale green, as nearly as possible like the light of a glow worm highly intensified. As it passed under the moon it brilliancy caused the moon to look of a muddy yellow colour- 
like a street lamp in a November fog. A Times correspondent at Cheltenham says that the path of the body was almost due east and west, and the apparent time of flight about 20 ". The meteor was also observed at Southampton, Tunbridge Wells, and Beckenham.

\section{UNIVERSITY AND EDUCATIONAL INTELLIGENCE}

The Sedgwick Memorial Committee (Cambridge) have passed the following resolution, which has been sent to the ViceChancellor:- "That a communication be made on behalf of the Committee to the University to the effect that a sum of about $\mathrm{I} 2,000 \mathrm{l}$. is now at their disposal for a memorial to the late Prof. Sedgwick, and that the Committee are prepared to apply this money towards the erection of a new geological museum when a plan satisfactory to the Committee has been approved by the Senate."

On the nomination of Prof. Miller, Mr. W. J. Lewis, M.A., Fellow of Oriel College, Oxford, has been approved as Deputy Professor of Mineralogy for twelve months, from October $\mathbf{r}$, I878, Prof. Miller assigning to Mr. Lewis two-thircls of his stipend.

Mr. J. A. Ewing, B.Sc., F.R.S.E., has been appointed Professor of Mechanical Engineering in the University of Tokio, Japan.

\section{SCIENTIFIC SERIALS}

Bulletin de l'Acadćmic Royal de Belsique, No. I, r878.- In rescarches on Daltonism, here described, MM. Delbouf and Spring used a solution of fuchsine between two convergent plates of glass (the red is wanting in M. Delbœuf's sight). Thus a suitable thickness of red could be readily selected, and it was found that colours previously confounded showed notable differences. A solution of chloride of nickel interposed between objects and the eye produces in non-Daltonians the same confuilon as that of Daltonians. Fuchsine opposes and destroys the effect of chloride of nickel: so that the non-Daltonian in whom the latter produces confusions ceases to have these when he looks also through the fuchsine. Daltonism is regarded as merely an exceptional exaggeration of a peculiarity found in all cyes to a certain degree.-M. Terby furnishe; fifteen figures of Mars as observed during the opposition of 1877 . - The physio1 ogical action of Gelsemine, on respiration, circulation, and temperature, is described by MM. Putzey and Romiée.-M. de Koninck announced that his son found, in the Ardennes, the very rare mineral carpholite, hitherto only met with in the Harz and Bohemia.

No. 2.-From experiments with regard to the fertilising action of the grey chalk of Ciply, in Belgium (which contains II'50 per cent of phosphoric acid), M. Petermann concludes that bicalcic phosphate, called precipitated phosphate, and the phosphates of iron and alumina, have the same agricultural value as the phosphoric acid of soluble phosphates, that is, their phosphoric acid may be immediately assimilated by plants. He therefore advises the disuse of the Cipley Chalk, and he consiclers it can only be utilised in agriculture after its transforma. tion into precipitated phosphate. (M. Stas thinks this conclusion too absolute.) -M. Quetelet reviews observations of the movements of the magnetic needle at Brussels from $1828-76$. The magnetic line diverges very little from a central axis, with which it makes an angle of about $5^{\circ}$. It turns round this axis in a direction opposite to that of the earth's diurnal motion; the angle described annually is about $42^{\prime} \cdot 2$, and the complete revolution would appear to be effected in $5 \mathbf{I} 2$ years. The secondary movements and accidental displacements do not sensibly affect the principal secular movement.-M. Donny recalls experiments he made, in 1843, with Prof. Mareska, on liquefaction of gases. They often compressed air (with a hydraulic pump) in the capillary part of a manometer to more than 500 atm., and $M$. Donny thinks they may have liquefied the gas without knowing it.-MM. Navez describe a combination of an induction coil with the telephone for speaking at great distances. 'The induced currents are sent into the line, while the sending instrument is inserted in the local circuit connected with the battery. The receiving telephone is somewhat modified.-The subjects for prizes offered by the Academy for 1879 are announced in this number.
Reale Istituto Lombardo di Scienze \& Lettere. Rendiconti, vol. xi. fasc. iv. - vi. - We note the following papers in these numbers:--Deformative hypertrophy of the nails, by M. Sangalli.-Claustrophobia, by $M$. Verga.-Some experiments with the telephone, by M. Serpieri.-On the dominant diseases of the vine, by MM. Garovaglio and Cattaneo.-On the kinematics of a solid body, by $M$. Bardelli.-Lecture experiment (illustrating liquefaction of gases), by $M$. Brugnatelli.-An experiment on electrostatic induction, by M. Cantoni.-On a case of heterogenesis observed in nature, by MM. Battista and Corrado. -Reduction of argentic and ferric chloride, by M. Tommasi.Geological observations on the Carso di Trieste and the valley of the Recci with reference to water supply, by M. Taromelli.

The Bullotin de l'Académie Impériale des Sciences a'e St. Pétersbourg (t. xxiv. No. 4) contains the following papers of interest:-Development into converging series of the odd negative powers of the square roots of the function $\mathrm{I}-2 \eta \mathrm{U}+\eta^{2}$, by Dr. J. Backlund.-Variation of the volume of liquids through the effect of temperature, by $M$. Avenarius. - On some new forms of crystals of ilmeno-rutile, by $P$. Jeremejew.-On the development of excrescences (cephalodia) on the thallus of Lichen, Peltigera aphthosa, Hoffm., by M. Babikoff.-On a new case of divisibility of the numbers of the form $2^{2^{m}}+1$, found by the Rev. J. Pervouchine, by V. Bouniakowsky.-A note on the opposition of planets during I 877 , by A. Sawitch.-On an extremely slight earthquake observed by means of a very delicate level on May 10, 1877, by M. Nyrén.

Morphologisches fahrbuch, vol. iv., supplement, dedicated to Carl von Siebold. - On the cranial skeleton of alepocephalus, a clupeoid fish, by Prof. Gegenbaur, two plates, 42 pp.-Fossi? vertebræ, by C. Hasse, dealing with the relationship of the gentus Selache; two plates. The author believes this genus to have developed from Carcharodon in the tertiary period.-The gorilla's brain and the third frontal convolution, by Prof. von Bischoff, a controversial article referring to Prof. Broca's researches and views.-Contribution on the coral family Antipatharia, by G. von Koch.-The disposition and development of elastic tissue, by L. Gerlach, with two beautiful plates.-The development of the muscular structure of the human foot, by G. IRuge, $36 \mathrm{pp}$. one plate.

THE Notizblatt des Vereins fïr Erdkunde zu Darmstadt (iii. xvi. Nos. I 8 I to I92) contains some interesting statistical data from the Hessian Central Statistical Office. The papers of geological interest are: On the crystalline lime of Auerbach on the Bergstrasse, by R. Ludwig.-On the minerals found in the cavities of the melaphyr from Traisa and in the basalt of the Rossberg, by the same.-On the minerals and fossils fotund near Hering (Hessen), by the same.-Comparative account of the products of all Hessian mines during the years from 1860 to 1876 , by Herr Tecklenburg. - On the famna of the real Cyrene emery of Sulzheim, near Woerrstadt (Hessen), by Dr. O. Boettger.

\section{SOCIETIES AND ACADEMIES LONDON}

Royal Society, May 2.- "Preliminary Notes on Experiments in Electro-Photometry." By Prof. James Dewar, F.R.S., Jacksonian Professor, University of Cambridge.

Edmond Becquerel, in the year 1839 , opened up a new field of chemical research through the discovery that electric currents may be developed during the production of chemical interactions excited by solar agency.

Hunt, in the year 1840 , repeated, with many modifications, Becquerel's experiments, and confirmed his results.

Grove, in 1858 , examined the influence of light on the polarized electrode, and concluded that the effect of light was simply an augmentation of the chemical action taking place at the surface of the electrode.

Becquerel, in his well-known work, "La Lumière," published in 1868 , gives details regarding the construction of an electrochemical actinometer formed by coating plates of silver with a thin film of the sub-chloride, and subsequent heating for many hours to a temperature of $150^{\circ} \mathrm{C}$.

Egeroff, in 1877 , sugested the use of a double apparatus of Becquerel's form, acting as a differential combination, the plates of silver being coated with iodide instead of chloride.

The modifications of the halogen salts of silver when subjected: to the action of light have up to the present time been used most 